Orissa Journal of Commerce

Vol. 42, Issue 2, April-June 2021

ISSN: 0974-8482

(C) OJC India. All Right Reserved

URL: www.ojcoca.org

DOI: https://doi.org/10.54063/ojc.2021.v42i02.03

\title{
Assessment of Efficiency of Public Factoring Companies in India
}

\author{
Vilas Hangargi ${ }^{1^{*}}$ and Shivakumar Deene ${ }^{2}$ \\ ${ }^{1}$ Research Scholar, Department of Commerce, Central University of Karnataka, Kadaganchi, Karnataka. \\ E-mail: vilashangargi24@gmail.com \\ ${ }^{2}$ Assistant Professor, Department of Commerce, Central University of Karnataka, Kadaganchi, Karnataka. \\ E-mail:drdeene@rediffmail.com \\ ${ }^{*}$ Corresponding Author
}

To cite this paper

Hangargi, V., \& Deene, S. (2021).

Assessment of Efficiency of

Public Factoring Companies in

India. Orissa Journal of Commerce.

42(2), 31-40

Keywords

Efficiency, Public factoring companies, Assets utilisation,

Total assets turnover, Equity

turnover, Working capital

turnover.

JEL Classification

G17, G20, G11, G23

\begin{abstract}
This paper aims to examine and compare the efficiency position of public factoring companies in India. The efficiency ratios are employed to ascertain the company's efficiency and utilize its assets. The secondary data has been collected from the annual reports of the concerned companies. The average total assets turnover ratio indicates that all public factoring companies do not show efficiency in utilising total assets. The Canbank Factors and IFCI Factors have higher efficiency in equity turnover, which indicates that these factoring companies have utilised the equity capital properly to earn more revenue. The working capital turnover ratio explains that Canbank Factors have proper management in controlling the short-term assets and liabilities. The ANOVA results show that there is a significant difference in the efficiency position of public factoring companies, except for an insignificant difference concerning the total assets turnover ratio. Canbank Factors and IFCI Factors have better efficiency in terms of equity turnover and working capital turnover ratio.
\end{abstract}

\section{Introduction}

The economic development of any nation relies on the presence of an efficient, organized financial system. The financial system helps to provide the essential financial contributions for the creation of merchandise and services, promoting the prosperity and way of living of a nation's individuals. The fundamental duty financial system is to activate the reserve funds as cash and money-related resources and put them in profitable ventures.

A lot of working capital is tied up in the form of trade debt. The trade debt emerges from the credit sale to customers by a company/business. This credit sale leads to liquidity problems and consequently delays production and supplies. In India, the circumstances are that most organizations/ companies are catering to the requirements of a single large buyer, and these buyers are always known for deferment in paying his payment. To conquer this circumstance, the factoring service has been conceived. 
Funds from creditors and owners are invested in various assets to generate income/sales and profit. The better the asset management, the better the sales/income. The efficiency ratios are employed to ascertain the company's efficiency in utilizing its assets. These ratios are often called activity/ performance/turnover / efficiency ratio and indicate the sales/revenue frequency concerning its assets. The activity/efficiency ratio thus involves a relationship between sales/revenue and assets. A right balance between sales/revenue and assets often reflects good assets management. The higher ratio shows a better efficiency of the business.

Hence, this study attempts an in-depth efficiency analysis of public factoring companies in India. The analysis results, findings and suggestions are pointed out from this study will help the factoring companies to review their performance and better understand to keep improvising their performance.

\subsection{Mechanism of Factoring Business}

Day 90

(6) Balance $20 \%$ payment minus interest charges and service fees

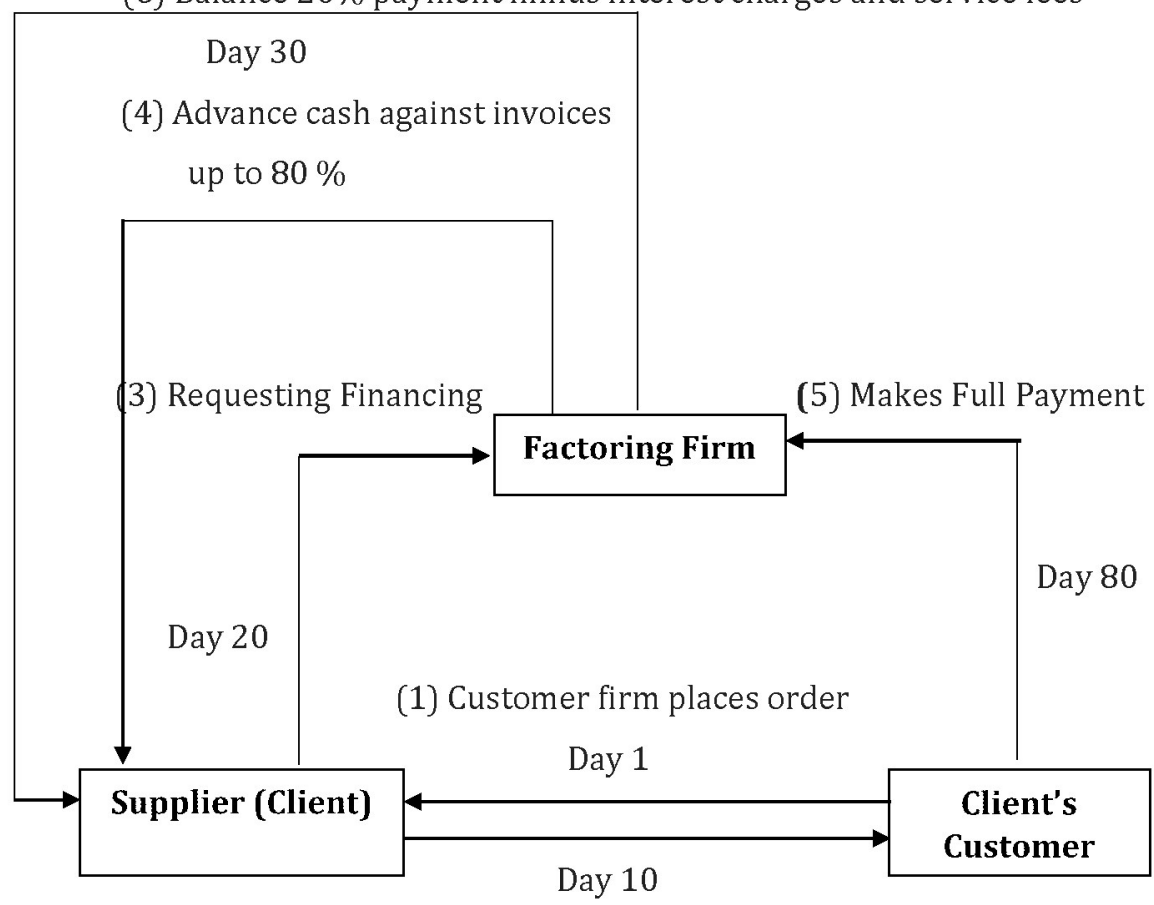

(2) Firm supplies goods and issues Invoices

Figure 1: Mechanism of Factoring Business

Source: Researcher Compilation 
- In the first stage (1), the customer places an order to the supplier to sell the goods on a credit basis.

- In the second stage (2), the supplier/client supplies goods on a credit basis and creates invoices in the usual mode.

- In the third stage (3), the client's customer's debt unpaid to the client is allocated to the factor by advising the client customer to pay the client's amount. And client handovers the invoices to the factor.

- The factor makes an instant payment of up to 80 percent of the allocated invoices in the fourth stage (4).

- Client customer makes the repayment of dues after agreed days for repayment (stage 5).

- After realizing payment from the client's customer, the factor pays the balancing amount by deducting interest charges and service fees (stage 6).

\section{Review of Literature}

The entire literature review is divided into four categories. Theoretical perspective, growth/prospects, financial performance, and technology usage.

\subsection{Theoretical/Conceptual Perspective}

Goyal (2011), in their study discusses the working, features, and factoring types. An attempt was also made to analyse the current factoring position and the Factoring Regulation Act, 2011. It points out some of the bottlenecks of the post Factoring Regulation Act, 2011. Hoti (2014) also describes factoring's overview and historical development and it focuses mainly on meaning, its types, and the advantages/ disadvantages of factoring.

\subsection{Growth/Prospects}

Junnaykar (2014) attempted to find the reasons behind the service's snail pace. In their study, the researcher considers that factoring performed very well in the initial few years but, later on, years it failed to carry out at the same pace. The researcher states some problems like- lack of awareness, better service from the banks, non-availability of credit insurance, fake bills, etc. Muthulakshmi (2014) affirms that SMEs in India are facing the challenges like non-availability of adequate/timely funds, delayed payments, lack of R\&D, lack of access to technical information and consultancy and problems relating to raising funds, traditional finance normally requires adequate security/collateral, perceived to be high risk. Finally, it concluded that the factoring business is yet to gain ground in India wherein SMEs struggle to get funding support from banks. Mohmad (2015) states that how the factoring service is considered an upcoming source of finance for SMEs in India. Factoring becomes even more popular, as did not require some sort of credit check. And small businesses, start-ups, and rapidly growing companies benefited significantly from factoring. Rao et al (2018) describe how the factoring institutions helping the business to meet their financial crunch, which resulted from the credit sale to their customers. And the researchers explain how the factoring institutions are adopting biased methods for gathering awful obligations, altering the image of factoring institutions and corporate employing factors. 


\subsection{Financial Performance}

Kalaivani (2013) tried to study the financial performance with specific parameters like-own funds, current liabilities, factoring income, etc. The researcher has taken two factoring companies, namelySBI Global Factors and Canbank Factors, and secondary data were collected for ten years from 1997 to 2006-07. The results of the study reveal that there is no significant difference among both factoring companies. Kaur \& Dhaliwal (2014) affirms that the financial performance of Canbank Factors was better than that of SBI Global Factors in terms of operating income, net profit ratio, return on equity, and return on assets. The researchers suggest that SBI Global Factors should utilize its assets more efficiently to earn a higher return on assets. Banerjee (2015) tried to suggest some lessons for Bangladesh by evaluating the Indian Factoring in terms of operational and financial performance. The study reveals that the operational and financial performance of the factors in India has been improving over time. Khan (2016) discovered that the Canbank Factors execution is better than the IFCI Factors.

\subsection{Technology Usage}

Vilas \& Praveen (2020) explain how the Trade Receivables Discounting System (TReDS) technology playing an essential role in making the human resources skillful and knowledgeable. This paper draws an overview of the new technology and how it helps the factoring business reach unreached customers, i.e., MSMEs and vice versa.

\section{Objectives and Hypothesis of the Study}

\subsection{Objectives of the Study}

- To study the efficiency position of select public factoring in India.

- To compare and highlight the overall efficiency position of public factoring companies with select variables.

\subsection{Hypothesis of the Study}

$\mathrm{H}_{\mathrm{a}}$ : There is a significant difference in the efficiency position of select public factoring companies.

\section{Research Methodology}

\subsection{Population and Sample of the Study}

For the study, all factoring companies in India are considered as the population. For the study sample, three public factoring companies have been selected, which are registered with RBI as "NBFC Factors" as of March 29, 2020, were selected. The registered public factoring companies are:

- SBI Global Factors Limited.

- Canbank Factors Limited and

- IFCI Factors Limited. 
Assessment of Efficiency of Public Factoring Companies in India

\subsection{Data Collection}

The data for the study is secondary. They have been collected from the annual reports of the select public factoring companies (2013-14 to 2017-18).

\subsection{Tools Used for Analysis}

The efficiency ratios like- total asset turnover, equity turnover, working capital turnover, and current assets turnover ratio have been used. The descriptive statistical tools like- mean, standard deviation and coefficient of variance have been used to conclude. To test the hypothesis, ANOVA has been used. The following efficiency ratios have been used.

- Total Assets Turnover Ratio

- Equity Turnover Ratio

- Working Capital Turnover Ratio

- Current Assets Turnover Ratio

5. Data Analysis and Interpretations

\subsection{Results of Total Assets Turnover Ratio}

Table 1: Total Assets Turnover Ratio (In No. of Times)

\begin{tabular}{lrrr}
\hline Year & $\begin{array}{r}\text { SBI Global } \\
\text { Factors }\end{array}$ & $\begin{array}{r}\text { Canbank } \\
\text { Factors }\end{array}$ & $\begin{array}{r}\text { IFCI } \\
\text { Factors }\end{array}$ \\
\hline $2013-14$ & 0.12 & 0.11 & 0.14 \\
$2014-15$ & 0.09 & 0.13 & 0.12 \\
$2015-16$ & 0.08 & 0.12 & 0.10 \\
$2016-17$ & 0.09 & 0.18 & 0.12 \\
$2017-18$ & 0.07 & 0.09 & 0.11 \\
Mean & 0.09 & 0.12 & 0.12 \\
SD & 0.02 & 0.03 & 0.02 \\
CV \% & 17.42 & 26.69 & 13.31 \\
\hline
\end{tabular}

Source: Authors' Calculations

Table 1 depicts the total assets turnover ratio of public factoring companies for a period of five years from 2013-14 to 2017-18. The SBI Global Factors Ltd. has the highest ratio of 0.09 times for 201415 and 2016-17 and the lowermost ratio was 0.07 times for 2017-18. Whereas, Canbank Factors Ltd. has the highest ratio of 0.18 times for 2016-17 and the lowermost was 0.09 times for 2017-18. Similarly, IFCI Factors Ltd. recorded the highest ratio of 0.14 times for 2013-14 and the lowermost ratio was 0.10 times for 2015-16. The Canbank Factors and IFCI Factors have the mean value of 0.12 times, which means the companies have the higher efficiency in using the investments in total assets to earn revenue among the 
other public factoring companies under the study. Whereas, SBI Global Factors Ltd. recorded lower efficiency in utilising the total assets to earn revenue, as the mean value stands 0.09 times. The coefficient of variance (CV) of IFCI Factors Ltd. was $13.31 \%$, which means IFCI Factors Ltd. is more consistent. In contrast, Canbank Factors Ltd. has a CV of $26.69 \%$, which clarifies that the company is more inconsistent in terms of total assets turnover ratio among the other factoring companies under the study.

Table 2: Results Showing One-Way Results for Total Assets Turnover Ratio

\begin{tabular}{lccccccc}
\hline \multicolumn{7}{c}{ ANOVA } \\
\hline Particular's & $\begin{array}{c}\text { Sum of } \\
\text { Squares }\end{array}$ & $d f$ & $\begin{array}{c}\text { Mean } \\
\text { Square }\end{array}$ & $F$ & Sig. & Remarks \\
\hline Between Company's & .004 & 2 & .002 & 3.153 & .079 & $\geq 0.05$ Not \\
Within Company's & .007 & 12 & .001 & & & Significant \\
Total & .010 & 14 & & & & \\
\hline
\end{tabular}

Source: Authors' Calculations

Table 2 represents the ANOVA results for the total assets turnover ratio of select public factoring companies. Here the p-value is above the confidence level of 5 percent (i.e., 0.05). Thus, the results conclude that there is no significant difference in the total assets turnover ratio of select public factoring companies.

\subsection{Results of Equity Turnover Ratio}

Table 3: Equity Turnover Ratio (In No. of Times)

\begin{tabular}{lrrr}
\hline Year & $\begin{array}{r}\text { SBI Global } \\
\text { Factors }\end{array}$ & $\begin{array}{r}\text { Canbank } \\
\text { Factors }\end{array}$ & $\begin{array}{r}\text { IFCI } \\
\text { Factors }\end{array}$ \\
\hline $2013-14$ & 0.34 & 0.42 & 1.15 \\
$2014-15$ & 0.31 & 0.54 & 0.76 \\
$2015-16$ & 0.30 & 0.48 & 0.47 \\
$2016-17$ & 0.34 & 0.74 & 0.51 \\
$2017-18$ & 0.31 & 0.41 & 0.50 \\
Mean & 0.32 & 0.52 & 0.68 \\
SD & 0.02 & 0.13 & 0.29 \\
CV \% & 5.76 & 25.79 & 42.57 \\
\hline
\end{tabular}

Source: Authors' Calculations

Table 3 depicts public factoring companies' equity turnover ratio for a period of five years from 2013-14 to 2017-18. SBI Global Factors has the highest ratio of 0.34 times for 2013-14 and 2016-17, and the lowermost ratio was 0.30 times for 2015-16. Whereas, Canbank Factors have the highest ratio 
Assessment of Efficiency of Public Factoring Companies in India

of 0.74 times for 2016-17, the lowermost was 0.41 times for 2017-18. Similarly, IFCI Factors recorded the highest ratio of 1.15 times for 2013-14 and the lowermost ratio was 0.47 times for 2015-16. The SBI Global Factors had a mean value of 0.32 times, which means the company has a lower efficiency in using the equity capital to earn revenue among the other public factoring companies under the study. Whereas, IFCI Factors recorded higher efficiency in utilising the equity capital to earn revenue, as the mean value stands 0.68 times. The coefficient of variance (CV) of SBI Global Factors was $5.76 \%$, which means SBI Global Factors is more consistent. In contrast, IFCI Factors has a CV of $42.57 \%$, which clarifies that the company is more inconsistent in terms of equity turnover ratio among the other factoring companies under the study.

Table 4: Results Showing One-Way Results for Equity Turnover Ratio ANOVA

\begin{tabular}{|c|c|c|c|c|c|c|}
\hline Particular's & $\begin{array}{l}\text { Sum of } \\
\text { Squares }\end{array}$ & $d f$ & $\begin{array}{l}\text { Mean } \\
\text { Square }\end{array}$ & $F$ & Sig. & Remarks \\
\hline Between Company's & .322 & 2 & .161 & 4.746 & .030 & $\leq 0.05$ \\
\hline Within Company's & .407 & 12 & .034 & & & Significant \\
\hline Total & .728 & 14 & & & & \\
\hline
\end{tabular}

Source: Authors' Calculations

Table 4 represents the ANOVA results for the equity turnover ratio of select public factoring companies. Here the p-value is below the confidence level of 5 percent (i.e., 0.05). Thus, the results conclude that there is a significant difference in select public factoring companies' equity turnover ratio.

\subsection{Results of Working Capital Turnover Ratio}

Table 5: Working Capital Turnover Ratio (In No. of Times)

\begin{tabular}{|c|c|c|c|}
\hline Year & $\begin{array}{r}\text { SBI Global } \\
\text { Factors }\end{array}$ & $\begin{array}{c}\text { Canbank } \\
\text { Factors }\end{array}$ & $\begin{array}{r}I F C I \\
\text { Factors }\end{array}$ \\
\hline 2013-14 & 0.20 & 0.47 & 0.29 \\
\hline 2014-15 & 0.16 & 0.59 & 0.44 \\
\hline $2015-16$ & 0.16 & 0.56 & 0.40 \\
\hline 2016-17 & 0.18 & 1.09 & 0.36 \\
\hline 2017-18 & 0.16 & 0.73 & 0.46 \\
\hline Mean & 0.17 & 0.69 & 0.39 \\
\hline $\mathrm{SD}$ & 0.02 & 0.24 & 0.07 \\
\hline CV \% & 11.12 & 34.87 & 17.14 \\
\hline
\end{tabular}

Source: Authors' Calculations 
Table 5 depicts the working capital turnover ratio of public factoring companies for a period of five years from 2013-14 to 2017-18. The SBI Global Factors has the highest ratio of 0.20 times for 2013-14 and the lowermost ratio was 0.16 times for 2014-15, 2015-16, and 2016-17. Whereas Canbank Factors has the highest ratio of 1.09 times for 2016-17, the lowermost was 0.47 times for 2013-14. Similarly, IFCI Factors recorded the highest ratio of 0.46 times for 2017-18 and the lowermost ratio was 0.29 times for 2013-14. The SBI Global Factors had a mean value of 0.17 times, which means the company has a lower efficiency in using the working capital to earn revenue among the other public factoring companies under the study. Whereas, Canbank Factors recorded higher efficiency in utilising the working capital to earn revenue, as the mean value stands 0.69 times. The coefficient of variance (CV) of SBI Global Factors was $11.12 \%$, which means SBI Global Factors is more consistent. In contrast, Canbank Factors has a CV of 34.87 \%, which clarifies that the company is more inconsistent in terms of working turnover ratio among the other factoring companies under the study.

Table 6: Results Showing One-Way Results for Working Capital Turnover Ratio

ANOVA

\begin{tabular}{lrrrrrr}
\hline Particular's & $\begin{array}{r}\text { Sum } \\
\text { Squares }\end{array}$ & $d f$ & $\begin{array}{r}\text { Mean of } \\
\text { Square }\end{array}$ & $F$ & Sig. & Remarks \\
\hline Between Company's & .671 & 2 & .335 & 15.692 & .000 & $\leq 0.05$ \\
Within Company's & .257 & 12 & .021 & & & Significant \\
Total & .928 & 14 & & & & \\
\hline
\end{tabular}

Source: Authors' Calculations

Table 6 represents the ANOVA results for the working turnover ratio of select public factoring companies. Here the p-value is below the confidence level of 5 percent (i.e., 0.05). Thus, the results conclude that there is a significant difference in select public factoring companies' working turnover ratio.

\subsection{Results of Current Assets Turnover Ratio}

Table 7: Current Assets Turnover Ratio (In No. of Times)

\begin{tabular}{|c|c|c|c|}
\hline Year & $\begin{array}{r}\text { SBI Global } \\
\text { Factors }\end{array}$ & $\begin{array}{r}\text { Canbank } \\
\text { Factors }\end{array}$ & $\begin{array}{r}I F C I \\
\text { Factors }\end{array}$ \\
\hline 2013-14 & 0.13 & 0.12 & 0.16 \\
\hline 2014-15 & 0.11 & 0.13 & 0.14 \\
\hline 2015-16 & 0.09 & 0.13 & 0.13 \\
\hline 2016-17 & 0.10 & 0.19 & 0.16 \\
\hline 2017-18 & 0.08 & 0.10 & 0.16 \\
\hline Mean & 0.10 & 0.13 & 0.15 \\
\hline SD & 0.02 & 0.04 & 0.01 \\
\hline CV \% & 18.57 & 27.76 & 7.57 \\
\hline
\end{tabular}

Source: Authors' Calculations 
Table 7 depicts the current assets turnover ratio of public factoring companies for the study years from 2013-14 to 2017-18. The SBI Global Factors has the highest ratio of 0.13 times for 2013-14 and the lowermost ratio was 0.08 times for 2017-18. Whereas Canbank Factors has the highest ratio of 0.19 times for 2016-17, the lowermost was 0.10 times for 2017-18. Similarly, IFCI Factors recorded the highest ratio of 0.16 times for 2013-14, 2016-17, and 2017-18 and the lowermost ratio was 0.13 times for 2015-17. The IFCI Factors has a mean value of 0.15 times, which means the company has the higher efficiency in using the current assets to earn revenue among the other public factoring companies under the study. Whereas SBI Global Factors recorded the lower efficiency in utilising the current assets to earn revenue, as the mean value stands 0.10 times. The coefficient of variance (CV) of IFCI Factors was $7.57 \%$, which means IFCI Factors is more consistent. In contrast, Canbank Factors has a CV of $27.76 \%$, which clarifies that the company is more inconsistent in terms of current assets ratio among the other factoring companies under the study.

Table 8: Results Showing One-Way Results for Current Assets Turnover Ratio

\begin{tabular}{lrrrrrr}
\multicolumn{8}{c}{ ANOVA } \\
\hline Particulars & $\begin{array}{c}\text { Sum of } \\
\text { Squares }\end{array}$ & $d f$ & $\begin{array}{c}\text { Mean } \\
\text { Square }\end{array}$ & $F$ & Sig. & Remarks \\
\hline Between the Company's & .006 & 2 & .003 & 5.271 & .023 & $\leq 0.05$ \\
Within the Company's & .007 & 12 & .001 & & & Significant \\
Total & .013 & 14 & & & & \\
\hline
\end{tabular}

Source: Authors' Calculations

Table 8 represents the ANOVA results for the current turnover ratio of select public factoring companies. Here the p-value is below the confidence level of 5 percent (i.e., 0.05). Thus, the results conclude that there is a significant difference in select public factoring companies' current turnover ratio.

\section{Findings}

The average figures of total assets turnover ratio indicate that all three public factoring companies do not show efficiency in utilising the total assets. Based on the equity turnover ratio, it can be concluded that Canbank Factors and IFCI Factors factoring companies have better efficiency, which indicates that these factoring companies have properly utilised the equity capital. In the case of working turnover ratio, except for Canbank Factors remaining public factoring companies have lower working capital turnover ratios, which indicates that management is not efficiently utilised the short-term assets and liabilities to support revenue. From the current assets' turnover ratio, all public factoring companies under the study fail to maintain a good ratio, which shows that management fails to have a reliable strategy in short-term assets and liability. The ANOVA results revealed that there is a significant difference in the efficiency position of public factoring companies, except for an insignificant difference in the total assets turnover ratio. 


\section{Conclusion}

Factoring companies are meant for meeting the working capital requirements of the MSMEs by purchasing account receivables. The importance of factoring companies is that they provide the following services to the MSMEs - provide working capital and debt collection, credit risk assessment, sales ledger management, consultancy, off-balance-sheet financing, etc.

The study reveals that all three public factoring companies failed to utilise the total assets efficiently to earn more revenue. From the study, it is suggested that all public factoring companies under the study should focus on appropriately utilising the total assets to get more revenue. All the factoring companies need to diversify their services to other areas such as - hire purchase, leasing, etc., to earn more revenue. The SBI Global Factors should focus on the better management of equity capital to support revenue. From the analysis, it is found that the SBI Global Factors and IFCI Factors registered a lower working capital turnover ratio. Hence, the above two public factoring companies should effectively utilise short-term assets and liabilities to support the revenue.

\section{References}

Banerjee, P. K. (2002). Performance Evaluation of Indian Factoring Business: Some Lessons for Bangladesh. Bank Parikrama, 27(1).

Hoti, U. (2014). Factoring: A Financial Instrument. Interdisciplinary Journal of Research and Development, 2(2), 7-10.

Junnaykar, G. R. (2014). Factoring/; Snail Pace Process. International Journal of Advanced Research in Computer Science and Management Studies, 2(8), 291-294.

K. Bala Krishna, Subrahmanyam S., \& Rao G. Srinivasa. (2018). Factoring Business: A Financial Revival Strategy. International Journal of Trend in Scientific Research and Development, 2(4), 1064-1066.

Kalaivani, D. K. N. (2013). A Study on the Performance Analysis of Factoring Services in India. Namex International Journal of Management Research, 3(1), 21-31.

Kaur, H., \& Dhaliwal, N. K. (2014). Financial Analysis of Factoring Companies in India/ : A Study of SBI Global Factors and Canbank Factors. International Journal of Research in Management, Science \& Technology, 2(1), $30-34$.

Md. Aijaz Khan, A. S. (2016). Financial Performace Analysis of Factoring Business: A Study of IFCI Factors Limited and CANBANK Factors Limited. International Research Journal of Commerce Arts and Science, 7(12), 22 29.

Goyal, M.M.. (2011). Factoring-Still a long way ahead. International Research Journal of Commerce Arts and Science, 4(2), 812-818.

Mohmad, K. M. (2015). Factoring Services in India/ : A Study. International Journal of Applied Services Marketing Perspectives, 4(2), 1650-1656.

Muthulakshmi, P. (2014). Finance Factoring - An Untapped Resource for Indian SME's. Global Journal for Research Analysis, 3(11), 13-15.

Vilas, M. R., \& Praveen, S. K. (2020). Role of TReDS Technology in HRM at Factoring Business. Studies in Indian Place Names, 40(56), 698-707. 